\title{
Communities: Development of church-based counselling teams
}

\begin{tabular}{|c|c|}
\hline \multicolumn{2}{|c|}{$\begin{array}{l}\text { Author: } \\
\text { Stella D. Potgieter }{ }^{1}\end{array}$} \\
\hline \multicolumn{2}{|c|}{$\begin{array}{l}\text { Affiliation: } \\
{ }^{1} \text { Faculty of Theology, } \\
\text { North-West University, } \\
\text { Potchefstroom Campus, } \\
\text { South Africa }\end{array}$} \\
\hline \multicolumn{2}{|c|}{$\begin{array}{l}\text { Note: } \\
\text { This article is published in the } \\
\text { section Practical Theology } \\
\text { of the Society for Practical } \\
\text { Theology in South Africa. }\end{array}$} \\
\hline \multicolumn{2}{|c|}{$\begin{array}{l}\text { Correspondence to: } \\
\text { Stella Potgieter }\end{array}$} \\
\hline \multicolumn{2}{|c|}{$\begin{array}{l}\text { Email: } \\
\text { 23084642@nwu.ac.za }\end{array}$} \\
\hline \multicolumn{2}{|c|}{$\begin{array}{l}\text { Postal address: } \\
61 \mathrm{~A} \text { 3rd Avenue, Westdene, } \\
\text { Johannesburg 2195, } \\
\text { South Africa }\end{array}$} \\
\hline \multicolumn{2}{|c|}{$\begin{array}{l}\text { Dates: } \\
\text { Received: } 19 \text { Aug } 2013 \\
\text { Accepted: } 28 \text { Feb. } 2014 \\
\text { Published: } 26 \text { May } 2015\end{array}$} \\
\hline \multicolumn{2}{|c|}{$\begin{array}{l}\text { How to cite this article: } \\
\text { Potgieter, S.D., 2015, } \\
\text { 'Communities: Development } \\
\text { of church-based counselling } \\
\text { teams', HTS Teologiese } \\
\text { Studies/Theological Studies } \\
71(2) \text {, Art. \#2050, } 8 \text { pages. } \\
\text { http://dx.doi.org/10.4102/ } \\
\text { hts.v71i2.2050 }\end{array}$} \\
\hline \multicolumn{2}{|c|}{$\begin{array}{l}\text { Copyright: } \\
\text { (C) 2015. The Authors. } \\
\text { Licensee: AOSIS } \\
\text { OpenJournals. This } \\
\text { work is licensed under } \\
\text { the Creative Commons } \\
\text { Attribution License. }\end{array}$} \\
\hline \multicolumn{2}{|l|}{ Read online: } \\
\hline 口idz & $\begin{array}{l}\text { Scan this QR } \\
\text { code with your } \\
\text { smart phone or } \\
\text { mobile device } \\
\text { to read online. }\end{array}$ \\
\hline
\end{tabular}

Pastoral care is a biblical mandate to the Church to be involved in the lives of God's people. A key metaphor used by Jesus to describe his pastoral role was that of a shepherd. Thus, to be God's shepherds and instruments of healing and transformation in God's world is an imperative to all people, clergy and laity alike. The brokenness in South African society is strikingly apparent, exacerbated by the effects of exceptionally high criminal behaviour as statistics show. The demand for pastoral care and assistance with various personal problems is on the increase, with many non-church goers turning to churches for help. Also apparent in South Africa is the acute shortage of trained individuals to offer care and counselling. The task of offering care is not the sole responsibility of clergy, as all are called to be shepherds and caregivers. The importance and urgency in training church-based counselling teams cannot be overstated. More so in that we are becoming increasingly aware that not only are individuals in need of care, but whole communities are struggling with trauma and life's challenges, and often do not know whom to turn to. In pursuance of the realisation that pastoral care is the function and duty of all Christians, this article will delineate in particular an explanation of lay counselling, reasons for its importance including biblical foundations, where and how ordinary South Africans can get involved, and will propose certain models and approaches for getting started. These models will not be discussed in depth, but present an opportunity for the next. Teams for these models consist of professional counsellors, but ought not to be restricted to a select few, as all are called to this special ministry and can be trained for the task, which will include on-going supervision and mentoring. The overall purpose of this article is to highlight the urgency of training lay counsellors and some recommendations will be made how to apply it, in an attempt to be faithful to the biblical mandate and examples set by Jesus Christ.

\section{Introduction}

A grass roots movement of lay Christian counselling has proliferated throughout church congregations in the United States of America and beyond (Tan 1991,2011). Lay model developers have influenced tens of thousands of lay counsellors and perhaps millions of congregants through their writings and seminars (Garzon, Tan \& Worthington 2009:113).

The main purpose of this article is to show the urgency of training lay counsellors. I wish to emphasise the importance of pastoral care in local communities by developing lay church-based counselling teams. These teams may consist of professional counsellors but should not be limited to a select few, because pastoral care is the task of all Christians who have a special calling to this specific ministry. Clinebell (1984:25) describes pastoral care and counselling as 'the utilization by persons in ministry of one-to-one or small group relationships to enable healing empowerment and growth to take place within individuals and their relationships'.

According to a Gallup poll released in 2011, 55\% of American adults reported that religion was 'very important' in their lives whilst $24 \%$ stated that religion was fairly important (Gallup n.d.). Although I cannot find a South African view for this research I assume that it will be the same. Thus, it is not surprising that many people with mental health problems will first turn to a pastor or other religious leader before seeking psychological services from a professional therapist. The same research finds that even amongst people who declared that they never attended religious service, $16 \%$ reported that they sought guidance from clergy for assistance with personal problems (cf. Veroff, Kulka \& Douvan 1981: 25, 233).

Pastors do not carry the burden of being the congregation's sole caregivers. They have a team of gifted, trained, committed lay caregivers ready to minister to hurting people inside and outside the congregation. 
Lay people have a chance to use and strengthen their leadership and caregiving gifts in meaningful ministry serving others whilst experiencing tremendous spiritual growth, and people who are hurting no longer suffer alone. A caring Christian friend comes alongside them to provide emotional and spiritual care for as long as the need persists. The New Testament envisions a ministry to which all are called (Van Deusen Hunsinger 2006:x). Our unity in Christ, our dependence upon Christ, and our willingness to offer and receive help from one another are all part of a rich vision for the Church (Van Deusen Hunsinger 2006:27).

Congregations have a practical, powerful influence and the New Testament urges us to bear one another's burdens (Gl 6:2), to confess our sins and pray for one another (Ja 5:16), to encourage one another (1 Th 5:11), and to care for one another (1 Cor 12:25; Van Deusen Hunsinger 2006:ix), to equip God's people for the work of ministry, for 'building up the body of Christ' (Eph 4:12), to 'love one another as I have loved you' (Jh 13:34) and to 'go make disciples' (Mt 28:19).

Human beings need one another in order to be human (Van Deusen Hunsinger 2006:6). In pastoral care, real interdependence becomes a reality when we reach out to one another in love. Only as we consent to open our inner lives to each other will we grow in trust. Each of us is called to listen to and intercede for others on the basis of their true need. Each of us is called to give witness to the one who sustains and renews our lives. Each of us is responsible for exercising the gifts we have been given for the good of all (Van Deusen Hunsinger 2006:27).

It is our responsibility as the Church (pastors and lay persons alike) to care for people struggling with their pain, trauma, uncertainty and confusion. I believe God ordained the Church as God's primary instrument to tend to God's people, especially those who are hurting. The directive in the Gospel of John 21:15, 'Feed or tend my lambs...' is clear. However, we must admit that, generally speaking, as church leaders, we are not doing a very good job in this area (Crabb 1977:10). On the other hand ordained ministers are not merely providers of pastoral care but, more importantly, those who equip their congregations to provide it (Van Deusen Hunsinger 2006:x). Christian counselling does not yet, however, have its rightful place as a source of help or the recognition it should or could have (Pretorius \& Van As 2003:283). It is in this regard that $\operatorname{Tan}^{1}$ presents a case for the need for lay Christian counselling ministries. Collins also emphasises the role of the 'lay Christian counsellor' by stating: 'The layman, especially the Christian layman, must take greater responsibility in meeting the needs of those who seek solace, friendship, or counsel' (Collins 1995:viii). It is not only individuals but whole communities that have to deal with challenging life issues (cf. Louw 2004:3; 2008:63). Holistic caregiving is an important way by which religious

1.American spelling in titles of publications and quotes from American sources no changed. Elsewhere the British spelling is used. leaders can transform this irrelevance into direct engagement in healing the many forms of brokenness that are pandemic today (Clinebell \& McKeever 2011:2).

\section{Some South African statistics that challenge the Christian Church}

Statistics are alarming and emphasise the need for the Church to re-think our strategies in caring for God's people in their suffering:

- In South Africa 4.2 million people are unemployed (Nuus24 n.d.). At the heart of unemployment is a deep, wounding experience of rejection. Where support is provided those who are unemployed and their families suffer, but they endure. Their hope for the future does not die.

- South Africa is dealing with economic stress, political uncertainty, crime and social transition, which means that many citizens are feeling stressed to breaking point. Professor Schlebusch, a South Africa authority on stress and suicide, says that although many suicides and attempted suicides go unreported, South African suicide statistics are in general alarming (Peters 2011). South Africa has 22 suicides and 220 attempted suicides a day (Shamos 2010:1) and there has been a shift in suicidal behaviour from the elderly to younger people in South Africa (Schlebusch 2012:437).

- South Africa has the highest number of rape cases in the world, and every 17 seconds a woman is raped. A 2006 study showed that close to 55000 thousand cases of rape were reported in South Africa within that year and an estimated four hundred and fifty thousand rape cases went unreported. Between $28 \%$ and $30 \%$ of adults reported that their first sexual encounter was forced (Rape statistics).

- The 2010/2011 statistics showed that each day South Africans experienced some 40 murders, 181 sexual offences, 278 aggravated robberies, and 678 burglaries (South Africa News n.d).

How should the Christian Church respond to these alarming realities in our country and communities? How may we be faithful and responsible stewards of Jesus Christ's command to care for, or tend or feed his lambs? In response to these and other questions, I propose an enhanced focus on the training in and application of pastoral counselling, which I believe is central and critical in our relationships with God's people.

\section{Biblical foundations for ordinary ministry}

Our urgent task as the Church is to present a training paradigm that teaches non-professional people some basic ways of responding to those who are struggling. Galatians 6:1-2 not only mentions problems, but also instructs Christians to 'bear one another's burdens' when the burdens of life get heavy 'and in this way you will fulfil the 
law of Christ'. All Christians are called to bear one another's burdens, to intercede on behalf of others, and to build each other up (Van Deusen Hunsinger 2006:x).

Generally people with real needs and struggles often do not know where to get help from (Tan 1991:21). This is primarily the reason why the Church exists today. True Christianity that is centred in Jesus our Lord, responds positively to the call to 'love one another as deeply as Christ loves us' (Jh $13: 34 ; 15: 12 ; 1 \operatorname{Pr} 1: 22$ ) and to reach out to each other, to bear one another's burdens, and to be instruments of God's grace and healing, as we help one another. This directive was given by the apostle Paul to the early Christians, and it is a directive we hear again today: to get involved in burden-bearing or the 'restoring' of humanity. This 'restoring' ministry involves counselling in its broader sense: simply people helping people. Human beings were created for koinonia [the community]. The eye cannot say to the hand, 'I have no need of you,' nor the head to the feet, 'I have no need of you' (1 Cor 12:21; Van Deusen Hunsinger 2006:5).

Writing to lay people at Galatia, Paul says, do not 'become weary in doing good' (Gl 6:9) and encourages them further: '[A]s we have opportunity, let us do good to all people, especially to those who belong to the family of believers.'

Throughout the existence of the Church, believers have continued to encourage, care for, and challenge each other. This caring has since evolved into what we now know as lay counselling (Tan 1991:7-8).

In addition to the scriptural texts cited already, I believe Ephesians 4:1-16 give us clear biblical foundations for the laity's call to ministry:

- Unity of calling: the 'vocation or calling ... is what you do with who you are in Christ. Every believer has been called to be Jesus' disciple and to serve in the kingdom of God. This is the "one hope" to which we are called (Eph 4:4). Fundamentally, then, there is no clergy-laity distinction. All are called by God.'

- Unity of Ministry: there is one calling (Eph 4:1), there are many expressions of grace (Eph 4:7) and many gifts for ministry (Eph 4:11). It is because of such diversity, which reflects how essential and needed each of the various ministries are, that the unity of the whole body can be achieved. Each member of the body is therefore indispensable, and unity in ministry results as each part does its work effectively (Eph 4:16).

- Unity in common life: it is impossible for believers to be in Christ alone or live independently of each other without losing their spiritual health. The word 'together' is used frequently in an innovative way (e.g., Eph 2:5, 6, 19, 21, 22; 3:6; 4:16) (Stevens 1985:225).

The interdependence of every member in the body of Christ (also 1 Cor. 12) reflects this unity in the common life of all Christians. In Ephesians 4:16, Paul asserts that every member in his or her contact with other members supplies something the body needs. In order to be an equipped environment the local church must therefore be structured for relationships (Tan 2011). Thus Christ is the hidden centre of all our relationships. This is part of what it means to live in mutual relationships that characterise our koinonia [community] in Christ (Van Deusen Hunsinger 2006:9, 24).

\section{Pastoral counselling}

Counselling is not a discipline like dentistry or medicine which depends fundamentally on a growing amount of technical knowledge administered by highly trained professionals. Counselling is founded on a spiritual level and is centrally and primarily a relationship between people who offer care, and those who are hurting. Since effective counselling requires both an understanding of human functioning and a caring relationship with the person to be counselled there is a great need to identify mature Christians in local churches who are filled with the love and passion of Christ, and have them trained in counselling skills and insights (Crabb 1977:14).

Pastoral counselling is one dimension of pastoral care. Clinebell and McKeever explain pastoral care as follow:

Pastoral care is about empowering people to live life abundantly; embracing the good and resisting evil; following vocations, and finding God, transcendent and imminent, in the good times, the bed times, and the ordinary times of life. It involves the care of persons, relationships, institutions, and a culture. In addition, pastoral care is an on-going ministry activity - it can happen on the steps of the church, in an education class, from the pulpit, in the pastor's office, in a hospital room, or in a home visit. It is about supporting folk through the up and downs of their lives and helping them live as fully as possible in community. It also involves helping members of the congregation learn how to offer this kind of care and support to one another. Pastoral care, in its very essence, is supportive care. (Clinebell \& McKeever 2011:9)

However, a distinction needs to be made between care and counselling.

Heitink (1998:18) refers to cura generalis [general care] and cura specialis [individual or special care]. He describes general care as the mutual care that Christians give to one another in their ordinary daily relationships, and special care as pastoral care that is given to an individual by a pastor who has training in pastoral care and counselling skills. Pastoral care should, however, be a task of the total Christian community (Van Deusen Hunsinger 2006:4) - a task of ministering to one another and reaching out beyond us.

Although the counselling and care coin has two sides they are from the same coin. Both have to do with the relationship between one human being and another in which help is given towards solving problems of living. Both are about the caring for the inner lives of individuals and are vehicles that help individuals towards a journey from brokenness to wholeness. With today's complex human needs and demands for care whether physical, spiritual, social, or emotional - there are unique opportunities for the growing of churches. 


\section{Lay counsellor}

Counselling has been defined as a caring relationship in which one person tries to help another deal more effectively with the stresses of life (Collins 1986:7). That is why pastoral care can be seen as koinonia. Koinonia is the telos [goal] as well as the indispensable means of all true pastoral care (Van Deusen Hunsinger 2006:1). Koinonia is the fellowship that makes pastoral care possible. When koinonia flourishes, so does pastoral care. Jesus Christ is mediator of the fellowship not only between God and us, but also in our relationships with others (Van Deusen Hunsinger 2006:3).

Lay counsellors can be described as individuals who do not have all the training, education, experience or credentials to be professional counsellors, but who nevertheless are involved in helping people cope with personal problems. Lay counsellors have also been called non-professionals or para-professionals with little or no training or with some limited training in such skills (Tan 1991:14). They do not have advanced degrees in counselling and are not licensed mental health professionals. Some do their counselling work under the supervision of a licensed mental health professional (Tan 2011:10, 399). The most important role lay counsellors play is that they can generally be effective helpers (Tan 2011:10, 399).

I now wish to take a moment to concentrate on lay or ordinary counsellors in our local church. I prefer to use the word 'ordinary counsellors': firstly, it places substantial emphasis on the value of life - on the everyday ordinary lives of believers; secondly, in using the term 'ordinary counsellors' I show that I acknowledge and respect what ordinary knowledge and experience bring to the field of pastoral counselling. This is especially important as neither the institutional church nor the academic community has paid much attention as yet to the voices of the so-called laity.

Clinton and Ohlschlager (2002:87) write that lay counsellors are recognised for their inherent empathy, listening ability, non-judgmental ways, compassionate caring, and friendly helpfulness; and they receive specialised training to enhance these qualities. They are very lay-intensive. We could all learn from their natural friendliness and the ease with which they relate to people, and we should seek to imitate their interpersonal model, which evinces the best kinds of helping and human relations. They are the people who will assist people in crossing bridges and in developing spiritual disciplines that promote the imitation of Jesus Christ (Clinton \& Ohlschlager 2002:419). Ordinary counselling has many positive aspects and has much potential in ministry. Reasons why the training of ordinary people for pastoral care in local communities is of utmost importance are:

- Firstly, ordinary counsellors who engage in pastoral care will highlight, bless, and strengthen the care that is already being offered by professional people.

- Secondly, it will increase the confidence of those people who desire to care for others but feel they are lacking in skills or ability. Because they lack skills or ability ordinary counsellors often tend to make excuses such as:
'I am not trained to do that sort of thing' or 'I don't know what to say'. These are not just excuses but the genuine apprehension of many people. They may either respond by giving advice (sometimes incorrectly) or stand on the side-lines wanting very much to help but are afraid to get involved. The majority of them have not been trained. They do not believe in themselves and feel that they are incapable to assist people in life's crises.

- Thirdly, the pastor should not and cannot be the only one who cares for others on behalf of the Church (Stone 1991:13). Ordinary counsellors should assist the pastor. One pastor for instance said: "The daily pressure of ministry can sometimes overwhelm me. People struggle in life therefore to prevent burnout ... yes I need laity to help me'. God joyfully employs an infinite variety of means to bring health and well-being to God's people. Pastors do not always have the time and means to help all those who are in need. Another pastor stated that '... with today's complex human needs, demands for attentive care I need a whole team to assist me. This is where the laity comes in'. Stone (1993:14) notes that lay persons doing crisis work are a natural extension of the Church's network of care. At least two considerations motivate a pastor's concern to develop lay caregivers. Firstly, if he attempts to fulfil the ministry of caregiving alone, he will be overwhelmed. Pastors cannot lead alone. They need others to come alongside to assist and encourage. Secondly, it is the pastor's responsibility to train church members to use their gifts for the edification and growth of the body (Eph 4:15-16; Clinton \& Ohlschlager 2002:408).

- Fourthly, ordinary counsellors offer care to people who might not get help otherwise (Garzon, Tan \& Worthington 2009:114), as many do not have medical aid insurance to cover the high cost of professional counselling or therapy, whilst others do not see the necessity to use their medical aid for this purpose. Counselling involves a continuing relationship and many are not able to afford continued professional therapy because of financial difficulties (Tan 2011:355). In some cultures, people do not see the need to go to a counsellor, because they feel the extended family unit, such as elders, parents, uncles, aunts, and other relatives, exists for that purpose. Family members are, however, often not as objective as an outsider. Objectivity helps people to get a new and better perspective on life and their problem situations.

- Fifthly, certain people are more trusting of ordinary caregivers (Garzon, Tan \& Worthington 2009:114) whom they know, compared to professional therapists whom they do not know. On the other hand some prefer outside intervention (a professional therapist) and not ordinary counsellors from their church whom they may know well. People who experience difficulties are not always able or willing to seek professional therapy, nor is it always necessary, but many need at least another person's assistance. And this is where the Church is able to meet people in their need.

- Lastly, the shortage of professional mental health workers or trained counsellors has led to an increased use of ordinary counsellors to provide mental health services 
to the millions who need them, to the extent that one author has referred to this trend as 'the nonprofessional revolution in mental health' (Garzon, Tan \& Worthington 2009:113). There are plus minus fifty thousand so-called professional or trained people in South Africa to help a population of 45 million, in other words, one trained person per 900 people (Swart 2006:7).

Another reason for training ordinary people is the potential reshaping of the Church's theology and the revival of its existing ministry of care. 'Love one another' (Jn 15:17) becomes something active. 'But you are a chosen race, a royal priesthood, a holy nation, God's own people, that you may declare the wonderful deeds of him who called you out of darkness into his marvellous light', 1 Peter 2:9 says. The Greek word for 'people' here is laos [laity] (Stone 1991:28). The concept of 'the priesthood of all believers' can thus be put into practice in an extremely vital way (Stone 1991:8). The Reformation teaching on 'the priesthood of all believers' insists that the ministry belongs first not to a clerical elite, but to the entire body of Christ (Van Deusen Hunsinger 2006:x).

Ordinary human beings emerge as the agents of God's care for the total welfare of people (Van Deusen Hunsinger 2006:4; Kysar 1991:61). We are the instruments for God's love to reach the physical, social, economic and political, as well as the spiritual conditions of others. God does not choose to work alone. God creates co-workers (Eph 2:10) and partners in God's divine enterprise. As God's agents, we should never misunderstand our role and function in God's mission. We too have been the object of God's care, and now we are called and sent out by the divine caregiver. The power for our mission is not our own, but God's. And like an executive corporate manager, God delegates authority and power to the partners of the firm in order that its mission might be accomplished (Kysar 1991:61; Sider, Olson \& Unruh 2002: 68, 149, 184).

Sometimes people need somebody to walk with them to the throne of God and ask on their behalf for what they are perhaps too tired to ask. Agents of God march with these souls to the throne of God and cry out with them, treading softly as they become God's hands and feet.

\section{Getting started}

In recent years there has been a tendency to place the counselling responsibility on the shoulders of the pastor. But some of our pastors are either not trained not interested, or not available to meet the needs for counselling, as a result of too many other pastoral duties.

It is a wise pastor who can identify and mobilise members of his or her congregation for this important and sacred task. The time has come for pastors to look to the laity as partners in the duties of pastoral care. This is occasionally billed as something new, but in truth we are only reincorporating a traditional function of pastoral care that has fallen into disuse (Stone 1999:7). The church has to and must recruit ordinary counsellors as volunteers. These volunteers should receive proper supervision through on-going informal mentoring and training by skilled pastoral staff and or trained professionals.

There are several ways in which ordinary pastoral careers can be selected for inclusion in the training group:

- The training can be announced to the whole congregation, with an invitation to anyone wishing to attend the course.

- The pastor or pastoral care committee may select certain persons.

- An existing group in the church can be enlisted as the first group of trainees (such as evangelism committees, boards of deacons, social ministry groups and outreach committees) (Stone 1999:34).

An ordinary counsellor would need to have certain characteristics if he or she is to be effective. Although all Christians are called to evangelise, not all are equally effective. Ortberg (2001:60-61) declares that 'a calling is something you discover, not something you choose'. He mentions that Christian counselling must be holy work, and the call to do it takes place in that territory of the soul where your deep gladness meets the world's deep need.

Hence it is worthwhile to identify those individuals who have the spiritual gifts for counselling.

Ordinary counsellors should be willing to reach out to others (Ps 139:14; Jn 1:12; Jn 6:37; Lk 2:9-10, etc.) and they should have the time. Remember their routine will occasionally be interrupted by the needs of others.

They have to be emotionally stable persons. Their own problems and pains must be sorted out to the extent that it would not hinder in working with the needs of others. If a counsellor's own issues are not sorted out he or she may consciously or unconsciously avoid their own pain in a number of ways (Geldard \& Geldard 2008:269). The counsellor might deflect away from the painful issues by encouraging the person to talk about something else or the counsellor might try to comfort the person rather than to help him or her to deal with issues. The counsellor might attempt to encourage the person being counselled to pursue a course of action that in some way satisfies the counsellor's own needs. The counsellor may avoid facing both his or her own issue and the person's by failing to recognise the issues and subconsciously suppressing them.

Ordinary pastoral counsellors need to be a spirit-filled person because one cannot do ordinary pastoral counselling without the input of the Holy Spirit. By spirit-filled I mean by living in the presence of God. Tan (1991:87-90) stated that this person must be a spiritually mature Christian, a person with a personal relationship with Jesus Christ and with knowledge of basic biblical principles: therefore they must have a basic but broad knowledge of the scripture. 
This includes understanding biblical-theological truth, not recited dogmatically, but rather committing it to heart, meditating on it, and renewing the mind by which the transformation of one's being takes place.

They must be able to show empathy, unconditional love and have a positive regard for people. Rogers (1957:96) referred to the importance of empathy. He made it clear that it is vital to listen carefully, enter the world of the client, and communicate that we understand that world. Putting yourself 'into another person's shoes' and 'viewing the world through someone else's eyes and ears' are other ways to describe empathy.

They must be non-judgmental, accepting and validating their fellow human beings. A non-judgmental attitude is expressed through vocal qualities and body language and by statements that indicate neither approval nor disapproval (Ivey, Ivey \& Zalaquett 2010:209).

They must respect the boundaries set by others and a counsellor must also set boundaries. New counsellors sometimes have difficulty in knowing how to respond to direct and/or indirect invitations for friendship and closeness by a person being counselled (Geldard \& Geldard 2008:271).

An ordinary counsellor must be a person of high ethical standards who rates confidentiality as very important. Confidentiality is limited by the need to keep records, professional supervision, the law, the protection of others, participation in training conferences and cooperation with other professionals. Professional ethics relate to various issues: respect for the client; limits to the relationship with the client; responsibility to a client, the employing agency and the community; competence; referral to others; termination of counselling; legal obligations; and self-promotion (Geldard \& Geldard 2008:267).

The ordinary counsellors should know their limitations and should know when to stop and refer the person to a professional. They should also know who to refer to. Hence a network should be set up for inter-referral and support. The network should include professional counsellors, psychiatrists, psychologists, psychotherapists, social workers, police and Christians involved in the deliverance ministries.

It is important to clearly describe different ways of providing ordinary helping ministries. Tan (2011) has categorised service delivery into three major models.

\section{The informal, spontaneous model}

Christian counselling can be done spontaneously and informally in the existing church structure. Such a structure would include home cell groups, fellowship meetings or Bible study or discipleship groups, outreach or evangelism programmes, pastoral visitation teams, to name a few. Müller (2005:73) holds that pastoral theology 'happens whenever and wherever there is a reflection on practice, from the perspective of the experience of the presence of God'. The moment of praxis is 'always local, embodied and situated'.

Leaders in these ministries will be given some basic training in how to care for or counsel with people, but they do not usually receive regular, on-going and close supervision. Common supervision methods involve direct observation, observation using a closed-circuit TV, audio- or videorecording and analysis, and use of verbatim reports (Geldard \& Geldard 2008:280).

This first model is a common one found in many of our churches, making use of gifted ordinary people to care for and counsel with one another in informal settings and in spontaneous ways (Tan 1991:83). It offers guidelines for teaching practical caregiving skills (Van Deusen Hunsinger 2006:xiv).

The informal spontaneous model is suitable for and works well within a small church setting.

\section{The informal, organised model}

This model assumes that the counsellors should be an organised and well-supervised ministry which nevertheless should still occur in informal settings as far as possible (Tan 1991:84). Ordinary counsellors are to be carefully selected, trained and supervised. They are used in a ministry of caring and counselling through structures similar to the ones mentioned in the first model (Tan 1991:84).

These ordinary counsellors are given systematic training in helping skills and receive regular, on-going and relatively close supervision in their counselling ministry. This is usually done by a pastor or director of counselling and care in a particular local church (Tan 1991:84).

\section{The formal, organised model}

In this model the ordinary counsellors are carefully selected, trained and supervised. Counselling takes place in a specifically designated area such as a counselling centre or office set aside for this use. There will also be weekly or monthly staff meetings, which may be supervised by a professional counsellor. This formal organised model is more suited for larger churches that have greater resources, such as building facilities, an adequate budget and a large congregation with many ordinary persons interested in counselling (Tan 1991:85).

In Romans 12:8 we read that paraklesis is a spiritual gift (Tan 1999:27). Such gifts are distributed thought the body of Christ, as God wills, and are used for the purpose of edifying the Church. Not all members of the body have this gift of coming alongside to help. But many do, and these people must form the basis of an ordinary counselling program.

In this model, the counselling centre may extend its ministry by offering its services not only to the local church but to 
other churches in the area and also to the surrounding communities (Tan 1991:85-86).

These are suggestions and need to be adapted to fit each local setting. The pastor's role here is important as he or she will have an understanding of what is best for that congregation or community, and will guide the process appropriately.

\section{Where and how can ordinary counsellors get involved?}

A common trend in many of our churches is that committed Christians do wish to get involved in the ministries of the Church, but often do not know how to, or where to offer their services. As pastors and leaders, it is our responsibility to help people understand that the Church exists for the community: we are called to bring healing and transformation to God's people.

We can reach out to all people, whether they are in the church, people's homes, hospitals or nursing homes.

I will share my list of some areas, after many years' experience in this practice, where ordinary people can offer care (you may wish to add to this list according to the needs in your specific communities):

- those infected and affected by the HIV/Aids pandemic

- orphans and vulnerable children

- children and youth with drug related problems

- issues related to migrant workers and xenophobia

- the terminally ill and their families

- people going through separation or divorce

- teenage or unwanted pregnancies, including support to their families

- people in trouble with the law

- those who are traumatised because of experiences of crime

- empty nest syndrome - parents who have children leaving home for various reasons

- people who are lonely, especially our elderly

- the depressed

- the bereaved (widow)

- new members of the congregation and/or community

- those who are shut in or in a nursing home, as well as their families

- those who are inactive in church and in need of pastoral visitation

- parents and families with handicapped children

- single parents

- those who are unemployed

- those who suffered a significant financial setback

- people experiencing grief because of needing to relocate

- people going through retirement or forced early retirement

- persons affected by natural disasters - for example in our informal settlements nowadays

- those who are struggling with their faith in God.

\section{Conclusion}

In conclusion, pastoral care as an expression of love for a neighbour is not reserved only for the ordained, but it is the duty of all who have been transformed by God's redemptive love. Although there may be other distinctions between clergy and laity, in this respect we are all 'professionals' in Christ.

All are called to be God's instruments of healing and transformation in God's world. As mentioned earlier, Jesus' imperative is clear, to Peter and everyone, to 'feed or tend his lambs' (Jn 21:15).

Ordinary counselling is centrally and critically a relationship between people who are hurting, and those who offer care to God's people. In South Africa today many people are hurting and often do not know whom to turn to. But, thanks be to God, for establishing the Christian Church. The reason the Church exists today is for the community and not the other way around. The community does not exist for the Church.

All our churches are to be 'hospitals': for the sinners, the grieving and those who are lonely and hurting. The Church was not intended to be a museum for saints. In the language of the fourth Gospel (Jn 10:10) human wholeness is described as 'life ... in all its fullness'. The Church's mission is to be an abundant life centre, a place for liberating, nurturing, and empowering life in all its fullness in individuals, intimate relationships, society and its institutions.

The Lord Jesus has called us to carry each other's burdens (Gl 6:2) and to reach out to one another with his agape love (Jn 13:34-35). The ministry of ordinary helping is an integral part of the manifold ministries of the Church and an important adjunct to the practice of professional counselling. Lay-helping is, therefore, a crucial manifestation of the whole Church in soul-care helping ministry, and it will become even more important in the years ahead (Clinton \& Ohlschlager 2002:436).

\section{Acknowledgements Competing interests}

The author declares that she has no financial or personal relationship(s) that may have inappropriately influenced her in writing this article.

\section{References}

Clinebell, H., 1984, Basic types of pastoral care and counseling, Abingdon Press, Nashville.

Clinebell, H. \& McKeever, B.C., 2011, Basic types of pastoral care and counseling: Resources for the ministry of healing \& growth, Abingdon Press, Nashville.

Clinton, T. \& Ohlschlager, G., 2002, Competent Christian Counseling, Waterbrook Press, Colorado.

Collins, G.R., 1986, Innovative approaches to counseling, Word Books, Waco.

Collins, G.R., 1995, How to be a people helper, Wheaton, Illinois.

Crabb, L., 1977, Effective biblical counseling. A model for helping caring Christians become capable counselors, Zondervan Publishing House, Michigan.

Gallup n.d., American public media speaking of faith, viewed 02 August 2012, from http://www.gallup.com/poll/1690/religion.aspx 
Garzon, F., Tan, S.Y. \& Worthington, E.L., 2009, 'Lay Christian counseling and client expectations for integration in therapy', Journal of Psychology and Christianity 28(20), 113-121.

Geldard, K. \& Geldard, D., 2008, Personal counseling skills: An integrative approach, Charles C. Thomas Publisher Ltd., Illinois.

Heitink, G., 1998, Pastorale zorg: theologie - differentiatie - praktijk, Kok, Kampen.

Ivey, A.E., Ivey, M. \& Zalaquett, C.P., 2010, International interviewing \& counseling: Facilitating clients development in multicultural society, Books/Cole, Belmont.

Kysar, R., 1991, Called to Care: Biblical Images for Social Ministry, Augsburg Fortress, Minneapolis.

Louw, D.J., 2004, Mechanics of the human soul: About maturity and life-skills, Sun Press, Stellenbosch.

Louw, D.J., 2008, Cura vitae: Illness and the healing of life, Lux Verbi B.M, Wellington.

Müller, J., 2005, 'A postfoundationalist, HIV-positive practical theology', Practical Theology in South Africa, 20(2), 72-88.

Nuus24 n.d., Statistiek Suid-Afrika, 'Werkloosheid neem af', viewed 18 Augustus 2012 from http://afrikaans.news24.com/Suid-Afrika/Nuus/Statistiek-SA-Werkloosheid neem-af-20120207

Ortberg, J., 2001, If you want to walk on water, you've got to get out of the boat, Zondervan, Grand Rapids.

Peters, S., 2011, 'Suicide stats 'alarming' constitutes third largest cause of unnatura deaths in SA', viewed 31 Mei 2012, from http://www.iol.co.za/dailynews/news/ suicide-stats-alarming-constitutes-third-largest-cause-of-unnatural-deaths-insa-1.1132378\#.UbYqEvnvgna

Pretorius, F.J. \& Van As, K.H., 2003 'The need for more Christian counsellors', Koer 68(2/3), 279-293. http://dx.doi.org/10.4102/koers.v68i2/3.339

Rape Statistics, South Africa \& worldwide 2011, viewed 17 May 2012, from http://www.rape.co.za
Rogers, C., 1957, 'The necessary and sufficient conditions of therapeutic personality change', Journal of Consulting Psychology 21, 95-103. http://dx.doi.org/10.1037/ h0045357

Schlebusch, L., 2012, 'Suicide prevention: a proposed national strategy for South Africa', African Journal of Psychiatry 15, 436-440. http://dx.doi.org/10.4314/ ajpsy.v15i6.56

Shamos, J., 2010, 'Patients as partners', African Journal of Psychiatry 9, 327-328.

Sider, R.J., Olson, P.N. \& Unruh, H.R., 2002, Churches that make a difference, Grand Rapids, Michigan.

South Africa News n.d., Crime statistics in South Africa, viewed 02 May 2012, from http://southafricanews.wordpress.com/2012/01/23/crime-statistics-in-southafrica

Stevens, R.P., 1985, Liberating the laity downers: Equipping all the Saints for Ministry, Intervarsity Press, Grove.

Stone, H., 1999, 'Pastoral counseling and the changing times', Journal of Pastoral Care 53, 119-127.

Stone, H.W., (ed.), 1991, The caring church, Fortress, Minneapolis.

Stone, H.W., 1993, Crisis counseling, rev. edn., Fortress, Minneapolis.

Swart, C., 2006, 'Participatory pastoral care and the transformation of society', PhD thesis, University of South Africa, Pretoria.

Tan, S., 1991, Lay Counseling: Equipping Christians for a helping ministry, Zondervan, Michigan.

Tan, S., 2011, Counseling and psychotherapy: A Christian perspective, Baker Academic, Grand Rapids.

Van Deusen Hunsinger, D., 2006, Pray without ceasing: Revitalizing pastoral care, Grand Rapids, Michigan.

Veroff, J. Kulka, R.A. \& Douvan, E., 1981, Mental health in America: Patterns of helpseeking from 1957-1976, Basic Books, New York. 